\title{
STUDENTS' RESPONSE TOWARD THE IMPLEMENTATION OF MINDOMO IN WRITING DESCRIPTIVE TEXT AT THE SEVENTH GRADE THE STUDENTS IN CIMAHI
}

\author{
Annisa Novianti ${ }^{1}$, Evie Kareviati ${ }^{2}$ \\ 1,2 IKIP Siliwangi \\ ${ }^{1}$ annisanovianti21@ student.ikipsiliwangi.ac.id, ${ }^{2}$ ekareviati@gmail.com
}

\begin{abstract}
This study aims to describe students' responses toward the implementation of Mindomo in writing description text at seventh-grade students in Cimahi. This study used descriptive qualitative methods. The participant of the study is 33 students' junior high school in Cimahi. The result of this study showed that the implementation of Mindomo in teaching writing descriptive text gave positive responses to $81,80 \%$. This positive response was shown with the enthusiasm of students during the learning process. Aspects of attention get the largest average score of around 24.54, which shows students are more interested in the learning process of writing using the Mindomo application. Besides, the aspect of confidence and satisfaction get the lowest score 12, it can be seen that the students are lack of confidence and have a fear of writing.
\end{abstract}

Keywords: Mindomo, Writing Skill, Description Text

\section{INTRODUCTION}

In Indonesia, English is considered as a foreign language. The people used the local language as a first language and national language or Bahasa Indonesia as a second language. Based on the 2013 Curriculum, English is being taught in Junior high school and senior high school. The English language is one of the subjects of learning. Four skills should be mastered in learning a language like listening, speaking, reading, and writing. Writing is a productive skill and shows the learners' achievement in academics. Rizqiya, Pamungkas, \& Inayah (2017) in Rohmat \& Sadikin (2019) state that a person's academic success can be affected by writing skills.

The success in achieving the writing process can be measured by looking at a result of writing and student's responses. Hamalik (2001) in Muhlisin (2018) explained that response is the coordinated movement by one's perception towards any events in the environment. Responses are important in learning similarly in writing. It is has a connection to the objective of writing to gained by students. Febrianti et al (2015) in Muhlisin (2018) argue that the response of students and the task received has a connection. Teaching and learning processes inside or outside the classroom will improve the response of students. Majid (2013) in Muhlisin (2018) states students' responses can be seen in the learning or teaching writing process. It can be measured by an expression of the students', enthusiastic, enjoyment in the process of writing. According to Muhlisi (2018) the indicator of response can be seen as either happy (positive) and unhappy (negative). The students will be given a response toward expression in the writing process. Responses to writing processes related to the motivation of students.

Motivation can support the students' to learn English. Many students are hard to learn English, especially in the writing process. According to Cahya, Kusnadi, \& Anggraini (2018) The lack of motivation makes the students hard to learn English. The students have low motivation in 
writing process because they found difficulties in writing such as how to generate an idea, transferring information, found the topic into written form.

In solving those problems, the teachers need to find a way or strategy to increase students' interest and draw their motivation in writing. One of the media can be implemented in writing process is Mindomo. Mindomo is Mind mapping software. It can help the student in the writing process to generate an idea. According to Nazril et al (2017) in Pertiwi, Nopita, \& Candra, (2018) Mindomo can improve students' achievement in writing and also can motivate students in writing skills, it is effective as a prewriting tool. Besides, Pertiwi, Nopita, \& Candra (2018) stated that the way of writing can be useful and motivated students by Mindomo. The use of mindomo in learning to write can motivate students and facilitate students in making concepts in writing. The teacher observes students during the learning process to determine students' response to the implementation of mindomo

\section{Writing Skill}

Writing is a process of transferring the message, generating an idea, and express a feeling in written form. This idea support by Nunan (2003, p. 88) in Rohmat \& Sadikin, (2019) writing is a process to make an idea, express them, and establish into sentences and paragraphs included physical and mental activity. Besides Brown (2001, p. 336) in Kareviati, Yugafiati, \& Resmini. (2019) explain that "writing is a process of thinking." Thus, writing is a process to make ideas, organize, or arrange into sentences toward a paper as a result of mind. In process writing the students found to lack, and difficulties to produce a massage. According to Pertiwi, Nopita, and Candra (2018) the difficulties of students usually, the students confused to focus on the topic and grown ideas. It is hard for the students in generating the topic or idea.

\section{Mindomo}

Mindomo is a collaborative mind mapping software by Expert Software Application. It was released in February 2007. Mind Mapping is a simple technique for drawing information, ideas using visual thinking. Mindomo can combine a diagram or chat with a picture, audio, and video. Mind mapping is a tool for improving skills and performance a person can use for educational, employment, and personal. Mind mapping is easy to use, generating ideas, problem-solving, and collaborative learning.

\section{Descriptive text}

Descriptive text is a text to given information and describing something. Gerot (1995) in Widiyanti, Susilawati, \& Rosnija (2018) explain that description text is a kind of text that has been purposed to giving information. The framework of this kind of text is a description of a particular thing, animal, person, or other, for example, my pets, or our family. Alice (2007) in Sukma (2018) states that "Descriptive text describes a person, place, or thing so that the reader can picture it in his or her mind". Wardiman (2008) in Indriani, Zahrida, \& Hardiah (2019) state that description text has two parts in generic structure: Introduction is a part of introducing the participants, and description is a part of describing the participants.

\section{METHOD}

This study used descriptive qualitative methods. The research design was a basic qualitative analysis. According to Ary (2010) in Ningrum (2016) basic qualitative research offered descriptive explanation with their purposes of understanding a phenomenon, a process of point of view from the participants. This study was conducted in Junior High School in Cimahi, West 
Java. The class consisted of 33 students. The class was selected by the teachers. The instrument of study used questionnaires and interviews.

\section{RESULTS AND DISCUSSION}

\section{Results}

Students' responses toward Mindomo application in writing descriptive text in junior high school by giving questionnaires with "strongly disagree", "disagree", "neutral", "agree", and "strongly agree" options in their answer. The result divided into 3 options that are "strongly agree and agree", "neutral", and "disagree and strongly disagree". Based on figures 1 . Shown positive response toward the implementation of Mindomo application in learning English process, especially in writing descriptive text.

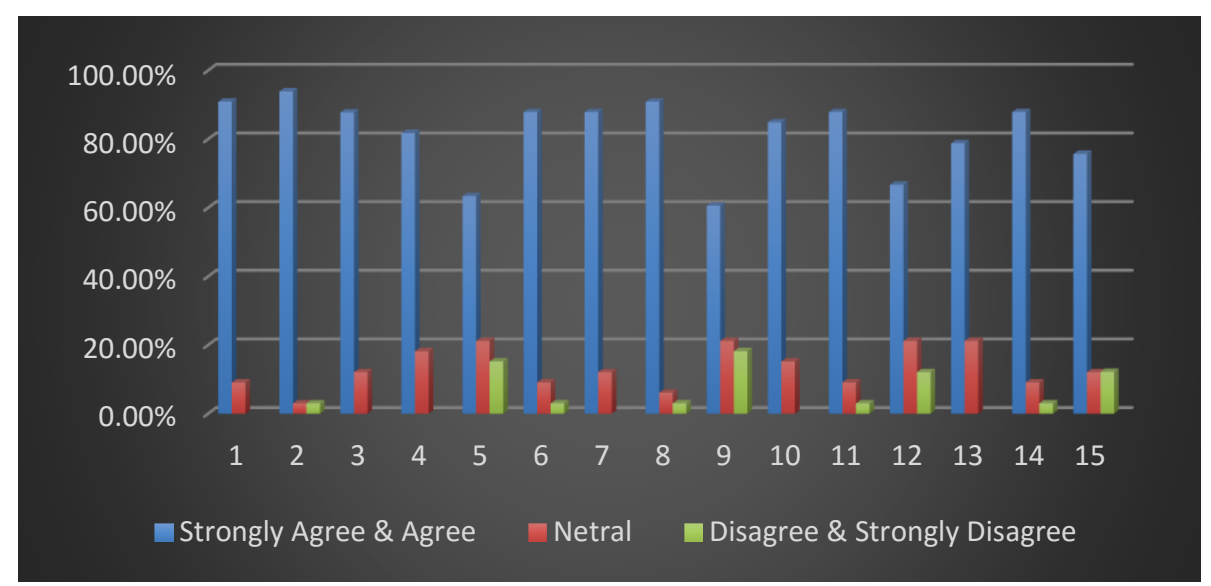

Figures 1. Result of students' responses toward the implementation of the Mindomo application.

The average score of students' responses showed positive responses in the learning process. Positive responses can be seen with the enthusiasm of students while learning. In the learning process, students strongly agree with the use of mindomo in the process of writing descriptive texts. Data shows that $81.80 \%$ of students agree with the implementation of Mindomo in the learning process of writing. Besides, disagree with students as much as $8.08 \%$. The data of average students' responses can be shown in figure 2 .

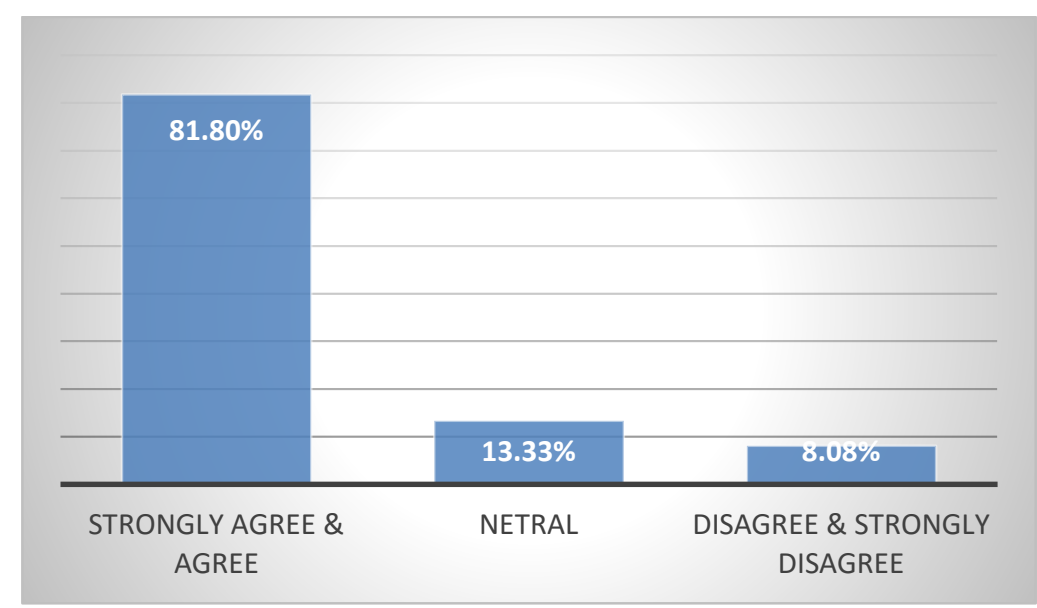

Figures 2 shows the average response of students. 
All of the statements given to students divided into 4 indicators included attention, relevance, confidence, and satisfaction. The result of each indicator shown in figures 3 . The aspect of attention-getting the highest average score is 24,54, and the lowest score is the aspect of confidence and satisfaction with an average score of 12. It can be explained that the attention of the students' in the learning process is highest, it contains enthusiastic and appreciative in learning. Students' interest in using Mindomo can be seen when they begin to apply Mindomo in writing concepts.

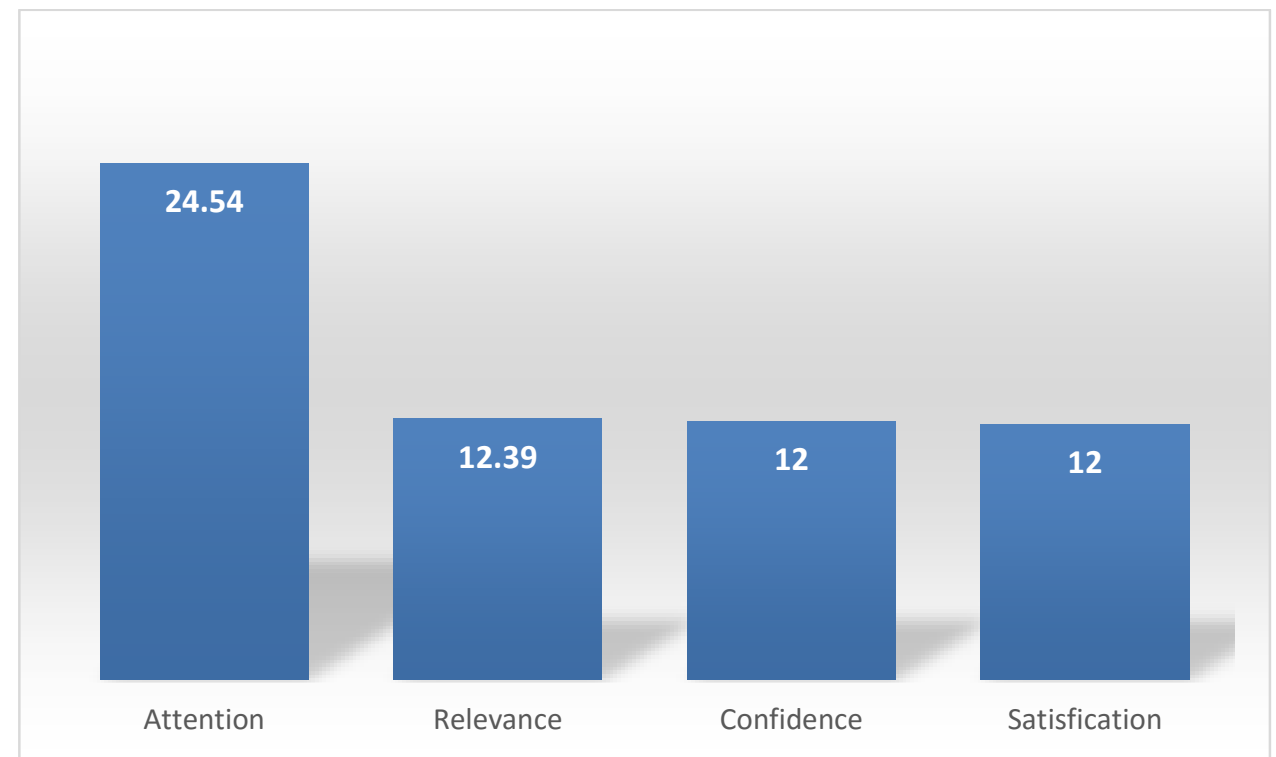

Figures 3. Average of students' responses on each indicator.

Furthermore, data is supported by interviews with students. The questions focused on students' responses toward the implementation of Mindomo application in the learning process. The results of interviews showed that $83.33 \%$ of students were very interested and excited during the learning process using Mindomo application. Especially in learning to write descriptive text, because students can make concepts about people who will be described. The students were helped by the exsistence of mindomo application in mapping their ideas.

\section{Discussion}

The research has intended to understand students' responses to the implementation of Mindomo application in the learning English process. The learning process has done with the Mindomo application for giving understanding the materials and then how to implement them. The process has done refered to 4 indicators they are attending (attitude and interest of students' toward the implementing of Mindomo application), relevance (capability for understanding and connecting an idea or keywords), confidence (motivation in learning and proficiency to make a concept), and satisfaction (bravery in developing ideas). The score is given 1 until 5 for each indicator, which indicated the highest score has a good assessment to use the Mindomo application).

In the learning process the students were given opportunities to make mind mapping related to the materials. Mindomo is pre-writing or brainstorming for the students before writing. The students are given the freedom to determine an idea. First steps, the students determine the topic that will be explained. After that, the students' tried to look for sub-topic to make mind mapping using the Mindomo application. Then, the students make the descriptive text following the 
concepts that have been made in the mindomo application. During the learning process, students are very enthusiastic about following the stages of using mindomo application.

Furthermore, the students can be more creative in making a concept map, as well as exploring their abilities. Based on data obtained from the result of previous studies Pertiwi, Nopita, and Candra (2018) on the title The Effect of Mindomo on Students' Writing Skills in class VII of SMPN 1 Tanjungpinang explained that Mindomo can make the students happy, enjoy, creative, and have motivation in writing descriptive text. Students are interested and focused on learning to understand the material and brave to share ideas. The students brave to give expression or deliver ideas with Mindomo.

\section{CONCLUSION}

Based on the statement above, the implementation of Mindomo in writing descriptive text at the seventh-grade students in Cimahi have a positive response. The majority of the students gave a positive response of $81,80 \%$ after the implementation of Mindomo in writing descriptive text. These responses can be seen with the enthusiasm of students during the learning process of descriptive text using Mindomo application. Meanwhile, the highest average value of responses given by students is around 24.54 on the aspect that shows the students are very interested in learning using mindomo. While the lowest value is shown in confidence and satisfaction with an average score of 12 , which shows that students felt afraid in expressing ideas in writing, so some students lack confidence in the writing process.

\section{ACKNOWLEDGMENTS}

Alhamdulillah, thank you Allah, my family, my lecturer and those who have supported this research.

\section{REFERENCES}

Cahya, T., Kusnadi, A. N., \& Anggraeni, A. (2018). The Influence of Tangible Rewards to Student'S Motivation in $4^{\text {th }}$ Grade SDN Sinargalih 1 Ciranjang Students. PROJECT (Professional Journal of English Education), $1(4), \quad 350$. Https://Doi.Org/10.22460/Project.V1i4.P350-356

Indriani, Rizka; Zahrida; Hardiah, M. (2019). The Effect of Guided Question Technique on Students' Writing Ability in Descriptive Text. Journal of English Education and Teaching, Vol 3 No. Https://Doi.Org/10.33369/Jeet.3.2.216-229

Kareviati, E., Yugafiati, R., \& Resmini, R. (2019). Need Analysis of English Department Students as The Basic of Material Development of. Eltin Journal, Journal of English Language Teaching in Indonesia, 8.

Muhlisin, A. (2018). Analysis of Students'response of The Implementation of Rms (Reading, Mind Mapping, and Sharing) Learning Model in Philosophy of Science. Unnes Science Education Journal, 7(1), 13-18.

Ningrum, C. H. (2016). The Use of Reader-Response Theory to Teach Reading Narrrative Text For Tenth Graders Of. 95-103.

Pertiwi, Ibra; Nopita, Dewi; Candra, M. (2018). The Effect of Mindomo on Students' Writing Skill at Seventh Grade of SMPN 1 Tanjungpinag. E-Journal Article. Http://Repository.Umrah.Ac.Id/1230/

Rohmat, N., \& Sadikin, I. S. (2019). The Impact of Peer Response on EFL Learners '. 5(1). Https://Doi.Org/10.25134/Ieflj.V5i1.1611.Received 
Sukma, D. E. G. (2018). The Use of Mind Mapping Picture to Improve Students' Writing Skill of Descriptive Text at Grade VIII oF SMP S Johan Sentosa. Al-Ishlah: Jurnal Pendidikan, 10(2). Https://Doi.Org/Https://Doi.Org/10.35445/Alishlah.V10i2.85

Widiyanti, Fiki; Susilawati, Endang; Rosnija, E. (2018). The Use of Clustering Technique to Teach Writing Descriptive Text. Jurnal Pendidikan Dan Pembelajaran Khatulistiwa, 7(8). Http://Jurnal.Untan.Ac.Id/Index.Php/Jpdpb/Article/View/27415 